\title{
Stock status of Nile tilapia (Oreochromis niloticus) in Aneuk Laot Lake, Sabang District, Aceh Province, Indonesia
}

\author{
EKO PRIANTO ${ }^{1, \vartheta}$, RUDY MASUSWO PURWOKO², KAMALUDDIN KASIM ${ }^{2, v \vee}$ \\ ${ }^{1}$ Department of Aquatic Resource Management, Faculty of Fisheries and Marine, Universitas Riau. Kampus Bina Widya, Jl. H.R. Subrantas Km 12.5, \\ Simpang Baru, Pekanbaru 28293, Riau, Indonesia. Tel./fax.: +62-761-63275, ^email: eko.prianto@1ecturer.unri.ac.id \\ ${ }^{2}$ Center for Fisheries Research, Ministry of Marine Affairs and Fisheries. Balitbang KP II Building 2nd floor, Jl. Pasir Putih, Ancol Timur, North Jakarta \\ 14430, Jakarta, Indonesia. "*email: kamaluddin.kasim@kkp.go.id
}

Manuscript received: 19 May 2021. Revision accepted: 22 July 2021

\begin{abstract}
Prianto E, Purwoko RM, Kasim K. 2021. Stock status of Nile tilapia (Oreochromis niloticus) in Aneuk Laot Lake, Sabang District, Aceh Province, Indonesia. Biodiversitas 22: 3364-3370. The Nile tilapia (Oreochromis niloticus) fishery in Aneuk Laot Lake plays a vital role in the local livelihoods. There is an indication of the massive exploitation of the species that potentially harm the stock and threaten its sustainability. This research aims to evaluate and assess the Nile Tilapia's stock status and use the results as baseline information to the management authorities. Surveys were conducted from May 2018 to April 2019 by collecting the length-weight data, sex, and gonadal maturity stage of 600 individuals. The Length-Based Spawning Potential Ratio (LB-SPR) was used to determine the Spawning Potential Ratio (SPR) and compared the results to the reference point. The results show that 50\% of the females have matured at $15.1 \mathrm{~cm}$, while the males at $17.8 \mathrm{~cm}$. The individual fish length varies from 12.15 to $20.5 \mathrm{~cm}$, whereas $50 \%$ of them were caught at size $17.8 \mathrm{~cm}$ (Lc50), meaning that predominantly of the fish had experienced first spawning before they were captured. The current SPR is about $5 \%$, confirming the Nile tilapia's stock status is at an unhealthy state. Consequently, the precautionary approach, such as increasing the mesh size and limiting effort, should be considered to ensure the sustainability of the recruitment.
\end{abstract}

Keywords: Aneuk Laot Lake, Nile tilapia, stock status, spawning potential ratio

\section{INTRODUCTION}

Aneuk Laot is one of the volcanic lakes that elevates about 25 meters above sea level and is located in Sabang District-Aceh Province, Indonesia. The lake provides daily freshwater needs for the locals. Generally, the lake's water level rises during the rainy season but rarely causes a flood to its adjacent areas. It has 10.5 million cubic meters, with 5.25 kilometers squares of catchment areas (Edyanto 2006). Since 2004, the lake has experienced water level reduction because of its leaks that allow water absorption into the fault. Yusifa et al. (2019) reported that the average reduction was about $10,800 \mathrm{~m}^{2}$ per year from 2004 to 2017, causing a substantial loss of the lake volume.

Besides its functionality to provide the daily freshwater needs to the local, Aneuk Laot Lake has also become the primary source of the inland fishery that supports local livelihood. The exploitation of a particular species has intensively developed in the area and might drain the resources. The Nile tilapia (Oreochromis niloticus) is one of the species that is fished since decades because the lake is the only place within the region where the inland fishery still occurred.

Khayra et al. (2016) reported that the lake has a low index of biodiversity. In his report, five species have been found in the lake, such as the Nile tilapia, mujair (Oreochromis mossambicus), snakeskin gourami (Trichopodus pectoralis), gourami (Osphronemus gourami), and snakehead (Channa striata). On the other hand, based on the interview results during the surveys, the fishers have noted a further three species which were bilih (Rasbora sp.), freshwater catfish (Clarias sp.), and aneuk gro (Rasbora spp.).

Fishers in Aneuk Laot Lake catch the Nile tilapia using small mesh gillnet and handline. Currently, smaller size and a lesser amount of the Nile tilapia were caught by fishers in Aneuk Laot Lake, indicating a fishing pressure has occurred within the decades. Based on that evidence, a stock status assessment of that economically important species is in need. Assessing the Nile tilapia's current stock status in Aneuk Laot Lake would support better management actions to maintain the sustainable use of the species and eventually benefit the community.

Length-Based Spawning Potential Ratio (LB-SPR) method developed by Hordyk et al. (2014b) was used to estimate the spawning potential ratio of the Nile tilapia in Aneuk Laot Lake. Likewise, Brooks et al. (2010), Nugroho et al. (2017) and Prince et al. (2020) also recommend that spawning potential ratio (SPR) can be applied to species with data-limited fisheries. Walters and Martell (2014) define the SPR as the number of eggs produced by an average recruit over its lifetime when the stock is fished, divided by the number of eggs that could be produced by an average recruit over its lifetime when the stock is unfished. In other words, SPR compares the spawning ability (or reproductive capacity) of stock in the fished condition to the stock's spawning ability (or reproductive capacity) in the unfished condition. This method was frequently used to assess marine fish stock status but has never been applied to the inland fish stock. In the inland 
fishery that lacks sufficient information to conduct the conventional stock assessment, the LB-SPR is preferred since it can be applied in a poor-data situation where length-frequency data is available.

\section{MATERIALS AND METHODS}

\section{Study area}

The survey was conducted in the Aneuk Laot Lake in Sabang District, Aceh Province, Indonesia from May 2018 to April 2019 (Figure 1). The individual fish samples were collected from gill-net fishers who landed their catch after fishing at several landing spots around the lake. Fishers catch fish for local consumption purposes; most of them use gill-net with mesh size range from 2 inches to 2.5 inches. Each sample was measured and weighed to collect length and weight data, the sex, and the gonadal maturity stage using visual observation. In this study, 600 individual fish consisted of 226 males and 371 females were collected and analyzed.

\section{Procedures}

The trained enumerators/observers are deployed in the field to collect the individual fish samples. All of the fish samples were examined fresh in the laboratory immediately after collection. The biological information such as maturity stage, length-weight data and sex differentiation of each individual fish are then recorded in each month so that the data are in one-year time series data. The maturity stage is determined according to the gonadal maturity stage manual book started from stage I to IV by visualizing the morphology of the individual fish sample, including the color, the shape, and the size of the gonad (Prianto et al. 2014)

\section{Data analysis}

The biomass was calculated for each age, while the "spawning stock biomass (SSB)" was defined as the total biomass of the fish that are matured (age at maturity). The spawning stock biomass (SSB) can be defined as below:

$$
S S B=\sum_{t=t m}^{t \lambda} N \tau x W \tau t
$$

Where, $W t$ is the average 'weight-at-age'. SSB is computed as 'pristine' (B0) under several management scenarios (Lc, F). The SPR was then calculated for a different level of Lc and F by dividing the exploited SSB over the 'pristine' SSB.

$$
S P R=\frac{S S B_{F}}{S S B_{F 0}}
$$

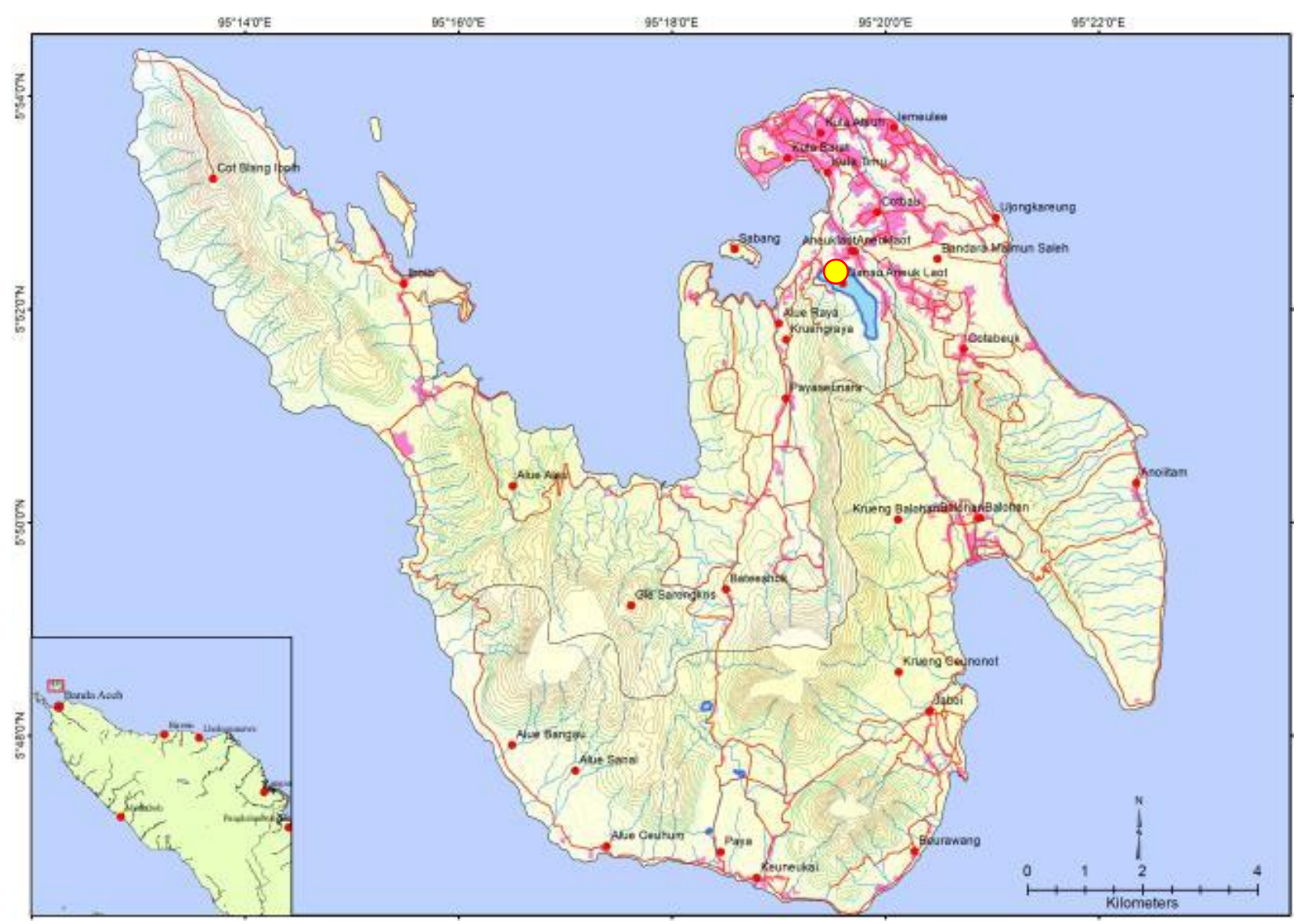

Figure 1. Map of Aneuk Laot $(\mathrm{O})$ in Sabang Island, Aceh Province, Indonesia 


\section{Length Based-Spawning Potential Ratio (LB-SPR) analysis}

The estimated parameters that resulted in LB-SPR analysis can be used as an indicator of the stock's status, as stated by Hordyk et al. (2014b). First, the ratio between natural mortality $(\mathrm{M})$ and Bertalanffy growth coefficient $(K)$ or $M / K$ should be known from previous research as a biological reference point, as well as other population parameters such as asymptotic length $\left(\mathrm{L}_{\infty}\right)$ and mature length $\left(\mathrm{L}_{\mathrm{m}}\right)$ of the Nile tilapia species. All the parameters were then used as inputs into the LB-SPR model developed by Hordyk et al. (2014b) using open-source statistical software R (R Development Core Team 2017).

Although the LB-SPR can be used to define the status of the Nile tilapia's stock, the computation on its SPR should stand on the precautionary approach once defining the population parameters of the species. The accuracy of the ratio between fishing mortality and natural mortality (F/M) highly depends on the computation of the selectivity that resulted from the model. The parameters population below, if added properly into the computation model, could end up with a more accurate SPR value.

The two-parameter logistic function modeled the maturity as follow:

$$
P=\frac{1}{1+e^{-\frac{\ln (19)(l-L 50)}{L 95-L 50}}}
$$

Where: $P$ : The maturity at length L; L50: length at $50 \%$ maturity; L95: length at $95 \%$ maturity.

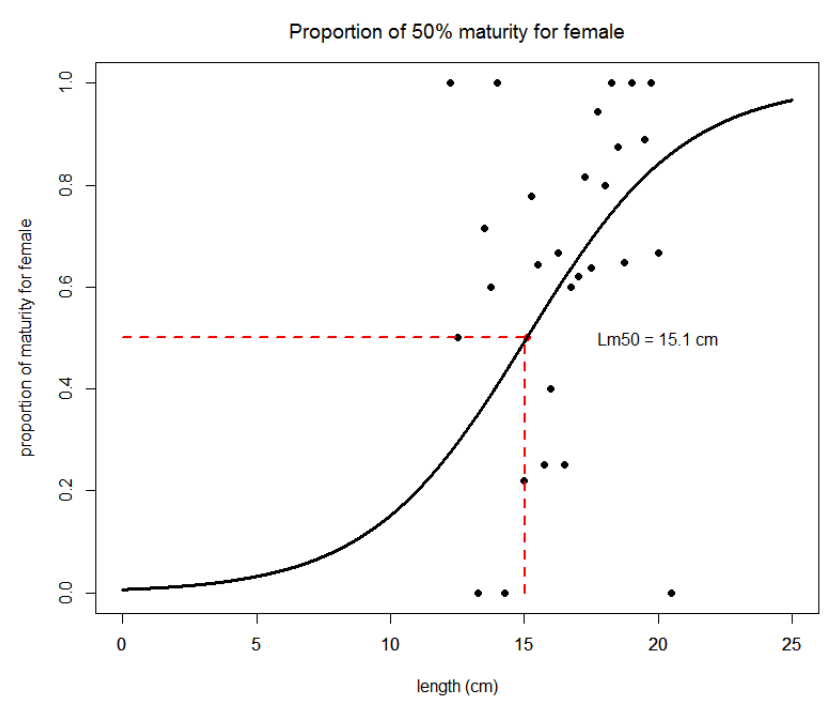

A

\section{RESULTS AND DISCUSSION}

\section{The length at first maturity}

The length of Nile tilapia harvested in Aneuk Laot Lake ranged from $12.25 \mathrm{~cm}$ to $20.5 \mathrm{~cm}$, while the weight ranges from 40 to 142 grams. Also, the dominant length varies from 16.5 to $18.5 \mathrm{~cm}$. These findings confirm some small size Nile tilapia have been harvested by the gillnet in Aneuk Laot Lake, raising the possibility of young fish being exploited in the fishery. The female fish seems to be matured early, resulting from the gonadal maturity analysis that shows $50 \%$ of the female has matured with an average length of $15.1 \mathrm{~cm}$ compared to the male fish that matured at $17.8 \mathrm{~cm}$ (Figure 2).

Figures 3 and 4 show the length of the Nile tilapia 17.8 $\mathrm{cm}(\mathrm{Lc})$ which is $50 \%$ retained by the gillnet compared to $50 \%$ of the female fish that matured at size $15.1 \mathrm{~cm}$. This result means some female fish had passed the mature stage and have spawned for the first time of their lifecycle before fishers captured them.

\section{The status of the stock}

Table 1 shows the SPR result computed using the LBSPR model showing SPR of the Nile tilapia has only $5 \%$ left after harvesting, and that is far below the limit of reference point 30 to $40 \%$. This low 5\% SPR point indicates the shortage of female biomass as affected by small net selectivity and may not provide future recruitment. Although the value of Lc is larger than Lm, it seems that only a tiny portion of the female biomass is passed through their first time spawning. In other words, the biomass of the female Nile tilapia that left after being fished is not good enough to produce eggs, so that the recruitment process may collapse to reach sustainable stock recruitment.

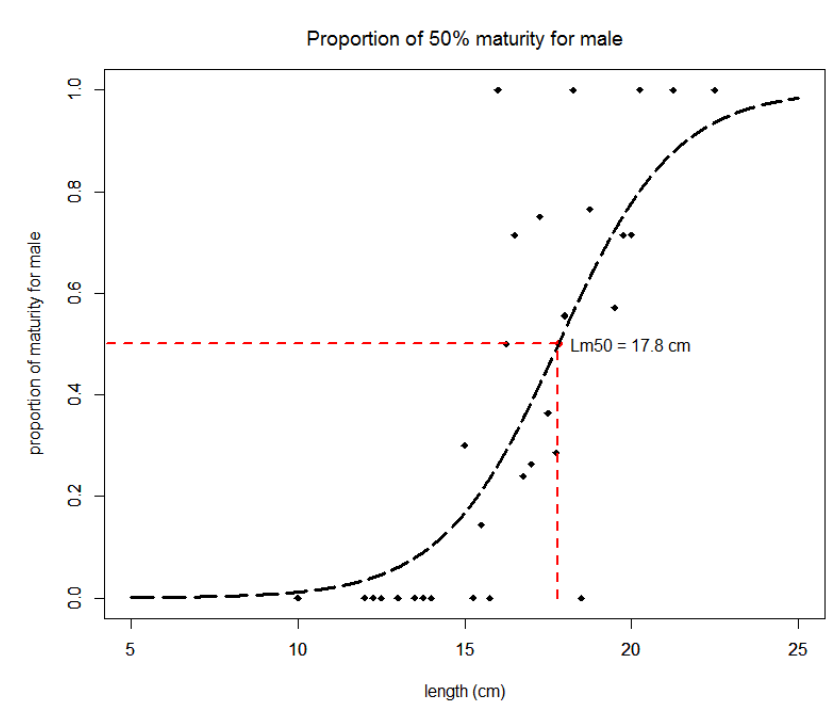

B

Figure 2. Length at 50\% maturity of the Nile tilapia female (A) and the male (B) that harvested in Aneuk Laot Lake-Aceh Province 


\section{Length at $50 \%$ maturity and selectivity of the tilapia}

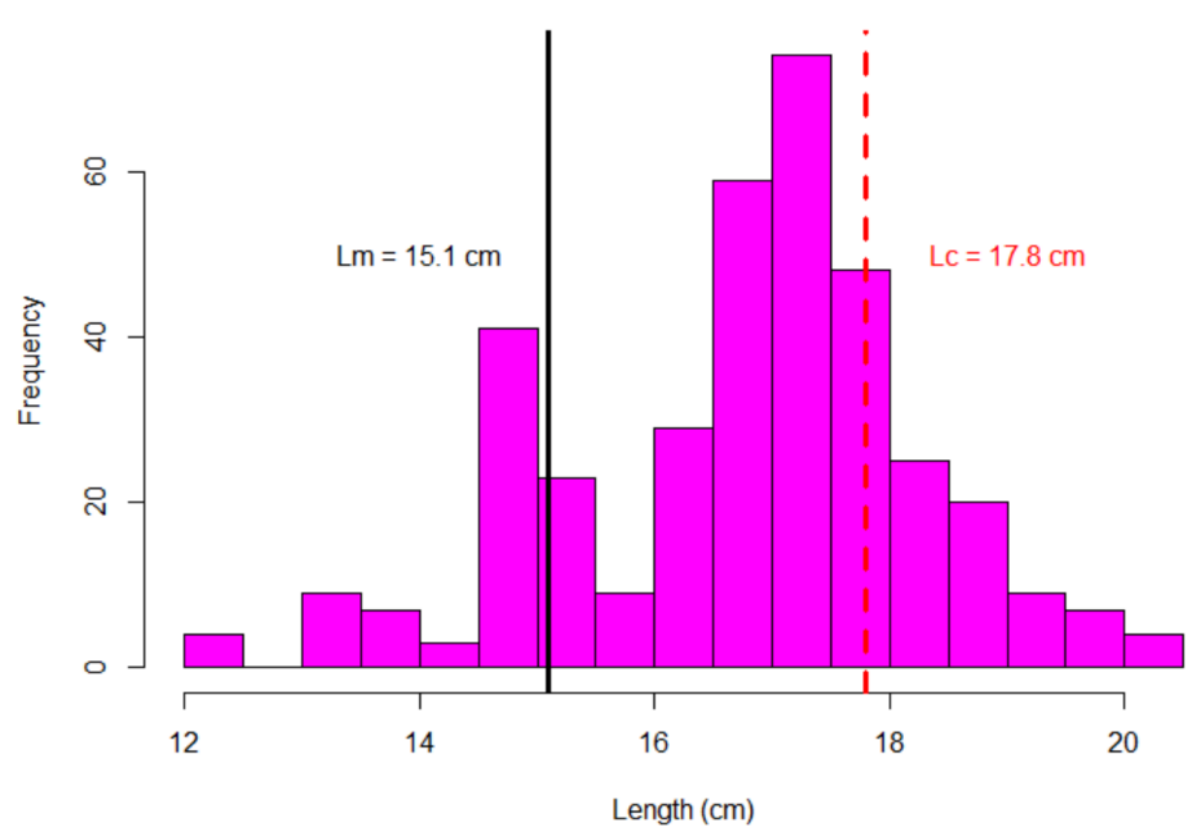

Figure 3. Length distribution, Lc50, and Lm50 of the Nile tilapia that retained using gillnet and handline in Aneuk Laot lake, Sabang District, Aceh Province, Indonesia. Note: Lm 50: Length at $50 \%$ maturity; Lc 50: Length at 50\% selectivity

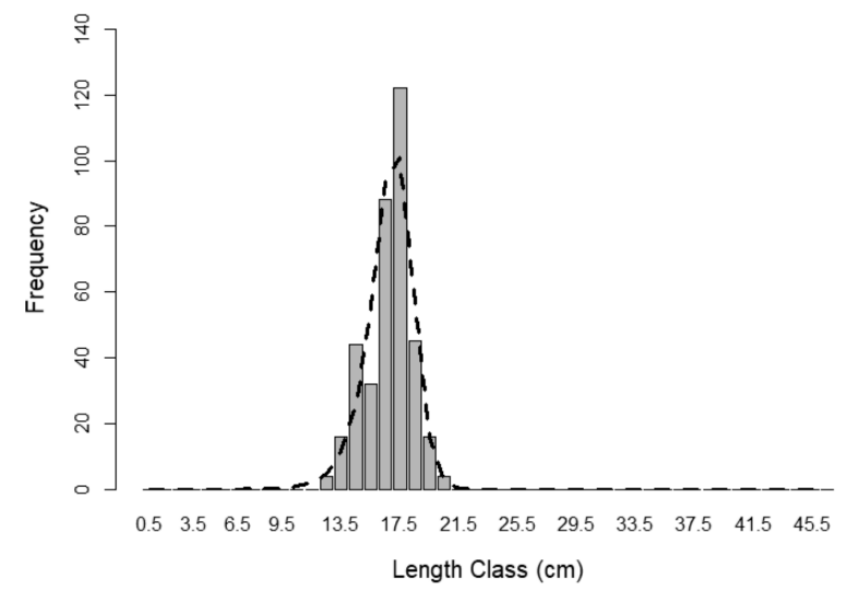

$\mathbf{A}$

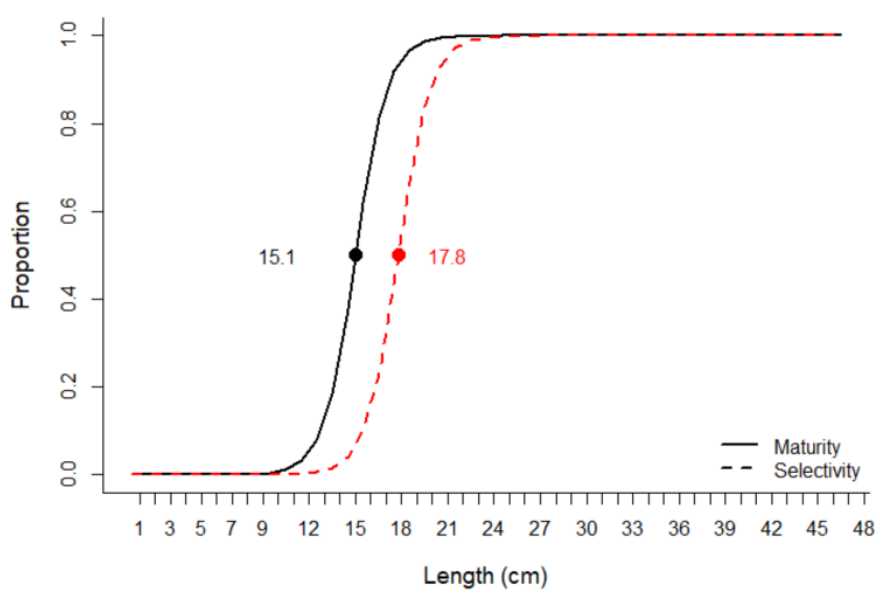

B

Figure 4. The length-frequency and selectivity of the net (black-dotted line on the left side) used to catch the Nile tilapia in Aneuk Laut. The right picture shows the comparison between length at selectivity over length at maturity

Table 1. The SPR, ratio of fishing mortality over the natural mortality (F/M), length at $50 \%$ maturity, length at $95 \%$ maturity, length at $50 \%$ selectivity, and length at $95 \%$ maturity of the Nile tilapia that harvested in Aneuk Laot Lake Aceh Province

\begin{tabular}{|c|c|c|c|c|c|c|}
\hline Species & Lc 50 female & Lc 95 female & Lm 50 female & $\mathbf{F} / \mathbf{M}$ & $\mathbf{E}$ & SPR \\
\hline Nile tilapia (O. niloticus) & $17.8 \mathrm{~cm}$ & $20.8 \mathrm{~cm}$ & $15.1 \mathrm{~cm}$ & 23.6 & 0.96 & $5 \%$ \\
\hline
\end{tabular}


Like the 5\%SPR, another indicator, the ratio of fishing mortality over the natural mortality $(\mathrm{F} / \mathrm{M})$, clearly indicates that high fishing pressure has occurred to the Nile tilapia fishery in the Aneuk Laot lake. The mortality rate caused by fishing is about 23 -folds higher than its natural mortality rate, as figured out in Table 1 . Therefore, management action on controlling the new effort that enters the fishery and regulating the gillnet's mesh size should take into consideration when managing the stock. Based on the interview results during the field trip surveys, fishers preferred to use gillnet with mesh size > 2.5 inches to minimize smaller fish retained in the fishing gear, and such effort could reduce the number of unmatured fish were retained from the fishing.

\section{Discussion}

In Asia, the Nile tilapia as introduced species (Bandara et al. 2020) is widely distributed in Indonesian inland waters and can be found at almost all lakes and reservoirs in Aceh Province (Muchlisin et al. 2017). This prominent local consumed-fish becomes one of the most wanted fishing targets, so that the fishery has experienced excessive fishing pressure because of its high market demand ( $\mathrm{Ng}$ and Romano et al. 2013). This long and intense fishing and the small mesh size of gillnet fishing within the narrow waters of Aneuk Laot lake may further risk the fishery itself.

A total of 600 individuals Nile tilapias were measured during the survey, with individual length, ranges from $12.25-20.5 \mathrm{~cm}$ and $40-142 \mathrm{gr}$ in weight. A study conducted by Salman and Mohammed (2020) showed that the size of Nile tilapia that were caught in Garmat Ali River, Iraq, which ranged from 8 to $25.5 \mathrm{~cm}$ in length and $8-325 \mathrm{gr}$ in weight was significantly higher than the Nile tilapia that caught in Aneuk Laot,. Another study conducted by Erni et al. (2014) found that males of the Nile tilapia caught by fishers in Aopa swamp ranged from 9.5 to $28.1 \mathrm{~cm}$ in length and 17-447 $\mathrm{g}$ in weight. Mehak et al. (2017) found the length of Tilapia (male and female) in Chasma Barrage, Pakistan from 5.2-21.7 cm and total weight from 5-105 g. Panda et al. (2018) stated that these differences in the growth of this species in different locations could be attributed to several factors, such as the environmental conditions, habitat, availability of food, metabolic activity, reproductive activity, the genetic constitution of the individual, fishing pressure and sampling method.

The length at first maturity $(\mathrm{Lm})$ of each species is quite different, or even with the same species but of different sex. For example, in this research, the female fish tend to have a small size to matured compared to the male fish. Craig et al. (2014) stated that the gonadal maturity stage in female fish is often found to mature early than the male fish, while Mustakim (2008) confirms that length at first maturity may be different for male and female fish as it occurs naturally. The length at first maturity of the Nile tilapia found in Aneuk Laot Lake is larger than the similar species found in a different habitat. For example, Sihwardoyo (2014) found that length at first maturity of the male Nile tilapia in the Sermo reservoir was $10.9 \mathrm{~cm}$, while $10.2 \mathrm{~cm}$ was recorded for the female. Another investigation conducted by Mohamed and Al-Wan (2020) in Garmat Ali River, Iraq, found the length for the female Nile tilapia could reach $8.0 \mathrm{~cm}$ while the male was slightly smaller 7.0 $\mathrm{cm}$. Furthermore, Alemu et al. (2017) found that the Lm of Nile tilapia in Lake Hawassa (Ethiopia) was 15.5 for females and then Mengist and Fakana (2020) found the $\mathrm{L}_{\mathrm{m}}$ of Tilapia in Alwero reservoir, Gambella, Ethiopia $<20 \mathrm{~cm}$ in length. Amarasinghe and Pauly (2021) have shown that Nile tilapia and other cichlids are exceptionally tolerant of stressful environmental conditions, but with elevated metabolism. They further emphasized that by reducing their growth and the maximum size they can reach 'stunting', they also reduce the sizes at which their maturity is initiated ('early spawning').

The study conducted by Erni et al. (2014) also confirms the larger sizes of Nile tilapia have been fished from Aopa swamp in South East Sulawesi compared to the Nile tilapia caught by fishers from Aneuk Laot lake in Aceh. In Aopa swamp, the average length of female Nile tilapia could reach $18.5 \mathrm{~mm}$ length while in Aneuk Laut Lake in Aceh, just about $15.1 \mathrm{~mm}$, or $16 \%$ larger than the Aneuk Laot's Nile tilapia.

The relatively smaller size of the Nile tilapia found in Aneuk Laot Lake might be related to environmental factors. For instance, according to the local fishers, an annual upwelling phenomenon in the lake where massive fish died during the event is often found. The upwelling event not only brings up the nutrient waters to the surface, but it also contains water with a high-sulphur content that is toxic to the fish. Local people believe this annual event is positively related to volcanic activity. This phenomenon is locally known as "tubo belerang" and might cause the lake categorized as a poor-nutrient lake, as reported by Edyanto (2006).

Tesfahun (2018) stated the size at first maturity of $O$. niloticus was correlated with availability of food, feeding rate, gonad development, spawning period, water quality parameters can determine the growth rate and the condition of fish and therefore, proper management of this fish stock for sustainable fishery is critical. Lagler et al. (1977) stated that external factors like temperature and water current and internal factors such as type of species, age, size, and physiological characteristics, are positively related to the reproduction capacity.

Also, Prianto et al. (2014) found that differences in length at first maturity for a particular species might relate to the factors like the abundance of the fish, environmental conditions, food availability, and fishing pressure. The fish stock that is experiencing high fishing pressure is most likely matured at a smaller size than the fish with no fishing pressure. This lesser in size might associate with the species' natural mechanism that forced them to reproduce more to sustain the species' existence. Amarasinghe and Pauly (2021) have shown that Nile tilapia and other cichlids are exceptionally tolerant of stressful environmental conditions, but with elevated metabolism. They further emphasized that by reducing their growth and the maximum size they can reach 'stunting', they also reduce the sizes at which their maturity is initiated ('early spawning'), substantiating the 'gill oxygen limitation 
theory (GOLT) of Pauly (2019). Evidence from the present study also support the GOLT (Pauly 2019; Amarasinghe and Pauly 2021)

The spawning potential ratio of the Nile tilapia in Aneuk Laut lake is very low at 5\% SPR, far below the threshold of $30 \%$ to $40 \%$ SPR. It also indicates the stock is at an unhealthy state and may hinder the biomass from recovering the replaced stock caused by fishing. Hordyk et al. (2014a) stated that the remaining biomass of the fish after harvesting should not be less than $30-40 \%$ SPR to ensure the recruitment's sustainability. The $30-40 \%$ SPR is the target reference point, which is often applied to almost all fish stock under well-managed fisheries. Powers (2019) argues that the SPR reference point should be $25-40 \%$ to ensure the sustainability of the stock.

Based on these results, it could be stated that the Nile tilapia fishery in Aneuk Laut Lake should be managed under a precautionary fishing approach, so the biomass after fishing still able to sustain the recruitment. For instance, the gear size regulation should only allow gillnet with mesh size above 2.5 inches to fish. These regulations could effectively avoid small fishes that have never experienced first-time spawning retained from the net. Another local wisdom, "panglima danau" could also contribute to the sustainability of the fishery since the fishers consistently follow the rule. This "panglima danau" local wisdom could be helpful as a local management measure because it is a community-based fishery management approach equipped with clear guidance on when and how to fish. For instance, fishers were not allowed to use potassium cyanide when gathering fish or abandoned their gear such as gill nets and traps since many left fish died and were trapped because of these destructive and ghost fishing practices. The 'panglima danau" also manages fishing time for all types of gears (trap, handline, and gillnet) where all fishing will be restricted every Friday, started from 7.00 AM to $1.00 \mathrm{PM}$ to honors the Friday prayer time. This unwritten rule also regulates penalties that are imposed on the fishers who violate the rule. For example, fishers caught using potassium cyanide will get penalties of 5.000.000 IDR (equal to $300 \mathrm{USD}$ ). About $20 \%$ of this money will go to the person who caught or reported the suspect, while the rest will be used to produce leaflets or brochures as part of the sustainable fishing campaign awareness. Another imposed penalty to those caught using a net with mesh size less than two inches will be sentenced to hand over all of their catches so the fish can be distributed to the poorer and orphans.

El-Kasheif et al. (2015) reported in El-Bahr El Faraouny Canal recommends to the local authorities to set a regulation controlling the illegal fishing activity and larger mesh sizes of fishing nets. Slightly larger mesh size can be useful to increase the mean lengths at first capture (Negese 2016) and their marketable sizes leading to more economic returns and conserve the spawning stock of Oreochromis niloticus population. Beaune et al. (2021) found the population of Nile tilapia in Nam Theun 2 Reservoir in Lao PDR is overfished with too many juveniles caught ( $\mathrm{L} 50=210.4 \mathrm{~mm} ; 50 \%$ mature stages at $295 \mathrm{~mm}$ ). Beaune et al. (2021); Yongo and Outa (2016) recommended maximizing the yield per recruit, increasing the biomass, and increasing the gillnet mesh size for the management of Nile tilapia.

The Nile tilapia stock harvested in the Aneuk Laot Lake has indicated an overexploited status since it is still far above the SPR reference point as the biological reference limit. Therefore, the management actions and precautionary approaches should consider ensuring the recruitment process can maintain healthy stock. Limiting the number of efforts that possibly enter the fishery and controlling the mesh size to the size of 2.5 inches is possible management actions that can be considered when managing the stock.

\section{ACKNOWLEDGEMENTS}

We thank the Director of the Center for Fisheries Research at the Ministry of Marine Affairs and Fisheries, Indonesia. This paper is part of the research "Study of Lakes and Reservoirs Capture Fisheries Status in the Fisheries Management Area (FMA) 431, 438, 439 and the Impact of Fish Restocking in the Fisheries Management Area 434," which is budgeted from the Center for Fisheries Research FY 2015.

\section{REFERENCES}

Alemu Y, Snoeks J, Teklegiorgis Y, Nyssen J, Brendonck L. 2017. Assessing sustainable fishing yields using length-based analytical models: A case study with nile tilapia in Lake Hawassa (Ethiopia). J Fish Livest Prod 5: 255. DOI: 10.4172/2332-2608.1000255

Amarasinghe US, Pauly D 2021. The relationship between size at maturity and maximum size in cichlid populations corroborates the Gill Oxygen Limitation Theory (GOLT). Asian Fish Sci 34: 14-22. DOI: 10.33997/j.afs.2021.34.1.002

Bandara KVSN, Kumara PADA, Amarasinghe US. 2020. Population dynamics of nile tilapia, Oreochromis niloticus (Linnaeus, 1758) (Teleostei, Cichlidae), in Some Irrigation Reservoirs of Sri Lanka. Asian Fish Sci 33: 192-204. DOI: 10.33997/j.afs.2020.33.2.010

Beaune D, Guillard J, Cottet M, Kue K, Lae R, Chanudet V, Descloux S, Tessier A. 2001. Investigating key biological parameters of Nile tilapia (Oreochromis niloticus L.) in a large Asian reservoir to better develop sustainable fisheries. Hydroécol Appl Tome 21: 157-179. DOI: $10.1051 /$ hydro/2020001

Brooks EN, Powers JE, Cortes E. 2010. Analytical reference points for age-structured models: application to data-poor fisheries. ICES J Mar Sci 67 (1): 165-175, DOI: 10.1093/icesjms/fsp225

Craig JF, Halls AS, Barr JJF, Bean CW. 2014. The Bangladesh floodplain fisheries. Fish Res 66: 271-286. DOI:10.1016/S0165-7836(03)001966.

Edyanto MCB. 2006. Penelitian kualitas air danau Aneuk Laot di Pulau Weh Propinsi Nangroe Aceh Darussalam. Jurnal Teknik Lingkungan 115-124. [Indonesian]

El-Kasheif MAE, Authman MM, Al-Ghamdi FA, Ibrahim S, Alaa ME. 2015. Biological aspects and fisheries management of tilapia fish Oreochromis niloticus (Linnaeus, 1758) in El-Bahr El-Faraouny Canal, Al-Minufiya Province, Egypt. J Fish Aquat Sci 10: 405-444. DOI: $10.3923 /$ jas.2015.405.444

Erni R, Asriyana, Mustafa A. 2014. Biologi reproduksi Ikan Nila (Oreohcromis niloticus) di Perairan Rawa Aopa Watumohai Kecamatan Angata Kabupaten Konawe Selatan. Jurnal Manajemen Sumber Daya Perairan 3 (2): 117-123. [Indonesian]

Hordyk A, Ono K, Sainsbury K, Loneragan N, Prince J. 2014a. Some exploration of the life history ratios to describe length competition, spawning-per-recruit, and the spawning potential ratio. ICES J Mar Sci 72 (1): 204-216. DOI: 10.1093/icesjms/fst235. 
Hordyk A, Ono K, Valencia SR, Loneragan N, Prince J. 2014b. A novel length-based empirical estimation method of spawning potential ratio (SPR), and tests of its performance for small-scale, data-poor fisheries. ICES J Mar Sci 72 (1): 217-2031. DOI: 10.1093/icesjms/fsu004.

Khayra A, Muchlisin ZA, Sarong MA. 2016. Morfometrik lima species ikan yang dominan tertangkap di Danau Aneuk Laot, Kota Sabang. Depik 5 (2): 57-66. DOI:10.13170/depik.5.2.4907. [Indonesian]

Lagler KF, Bardach JE, Miller RH, Pasino RM. 1977. Ichthiology. Jhon Wiley Sons Inc, Toronto.

Mehak A, Mu Y, Mohsin M, Noman M, Nazir K. 2017. Population dynamics of Nile Tilapia (Oreochromis niloticus) at Chashma Barrage, Pakistan. Indian J Geo Mar Sci 46 (1): 206-210. DOI: 10.1007/s11356-020-09234-w

Mengist AB, Fakana ST. 2020. Stock assessment and estimation of current yield for tilapia stock (Oreochromis niloticus) Alwero reservoir, Gambella, Ethiopia. Intl J Fish Aquat Stud 8 (3): 205-210.

Mohamed ARM, Al-Wan SA. 2020. Biological aspects of an invasive species of Oreochromis niloticus in the Garmat Ali River, Basrah, Iraq. J Agric Vet Sci 13 (2): 15-26. DOI: 10.9790/2380-1302011526.

Muchlisin ZA, Nurfadillah N, Arisa II, Rahmah A, Putra DF, Nazir M, Zulham A. 2017. Short communication: Fish fauna of Lake Lauik Tawar and Lake Laulo, Simeulue Island, Indonesia. Biodiversitas 18 (2): 752-757. DOI: 10.13057/biodiv/d180244.

Mustakim M. 2008. Kajian kebiasaan makanan dan kaitannya dengan aspek reproduksi ikan betok (Anabas testudineus Bloch) pada habitat yang berbeda di lingkungan Danau Melintang Kutai Kartanegara Kalimantan Timur. [Thesis]. IPB University, Bogor. [Indonesian].

Negese K. 2016. Stock assessment and estimation of optimum yield for tilapia stock (Oreochromis niloticus) in Lake Hawassa, Ethiopia. Poult Fish Wildl Sci 4: 156. DOI: 10.4172/2375-446X.1000156.

$\mathrm{Ng}$ WK, Romano N. 2013. A review of the nutrition and feeding management of farmed tilapia throughout the culture cycle. Rev Aquacult (2013) 4: 1-35. DOI: 10.1111/raq.1201.4.

Nugroho D, Patria MP, Supriatna J, Adrianto L. 2017. The estimates spawning potential ratio of three dominant demersal fish species landed in Tegal, north coast of Central Java, Indonesia. Biodiversitas 18 (2): 844-849. DOI: $10.13057 /$ biodiv/d180258.

Panda D, Mohanty SK, Pattnaik AK, Das S, Karna SK. 2018. Growth, mortality and stock status of mullets (Mugilidae) in Chilika Lake, India. Lakes Reserv Res Manag 23 (1): 4-16. DOI: 10.1111/lre.12205

Pauly D. 2019. A précis of gill-oxygen limitation theory (GOLT), with some emphasis on the eastern Mediterranean. Mediterr Mar Sci 20 688-702. DOI: $10.12681 / \mathrm{mms} .19285$
Powers JE. 2019. Spawning Potential Ratios (SPR) Interpretation and Application. School of the Coast and Environment, Louisiana State University, USA.

Prianto E, Kamal MM, Muchsin I, Kartamihardja ES. 2014. Biologi reproduksi ikan betok (Anabas testudineus) di paparan Banjiran Lubuk Lampam, Kabupaten Ogan Komering Ilir. Bawal 6 (3): 137146. DOI: 10.15578/bawal.6.3.2014.137-146. [Indonesian]

Prince J, Creech S, Madduppa H, Hordyk A. 2020. Length-based assessment of spawning potential ratio in data-poor fisheries for blue swimming crab (Portunus spp.) in Sri Lanka and Indonesia: Implications for sustainable management. Reg Stud Mar Sci 36: 101309. DOI: 10.1016/j.rsma.2020.101309.

R Core Team. 2017. R: A Language and Environment for Statistical Computing. R Foundation for Statistical Computing, Vienna, Austria. https://www.R-project.org/

Salman AN, Mohamed ARM. 2020. Growth, mortality and yield-perrecruit of nile tilapia (Oreochromis niloticus) in Garmat Ali River, Iraq. Asian J Appl Sci 8 (6): 350-360. DOI: 10.24203/ajas.v8i6.6397.

Samuel, Ditya YC, Adiansyah V. 2017. Dinamika populasi ikan nila (Oreochromis niloticus Linnaeus, 1758) di Danau Paniai, Papua. Jurnal Penelitian Perikanan Indonesia 23 (3): 193-203. DOI: 10.15578/jppi.23.3.2017.193-203. [Indonesian]

Sihwardoyo RW. 2014. Panjang Pertama Kali Matang Gonad Nila Hitam (Oreochromis niloticus) di Waduk Sermo Kabupaten Kulon Progo. [Hon. Thesis]. Departemen of Fisheries Recources Manajemen, Faculty of Agriculture, Gajah Mada University, Yogyakarta. [Indonesian]

Tesfahun A. 2018. Overview of length-weight relationship, condition factor and size at first maturity of Nile tilapia Oreochromis niloticus (L.) in different water bodies of Ethiopia: A review. Greener J Biol Sci 8 (3): 021-028. DOI: 10.15580/GJBS.2018.3.060618077.

Walters CJ, Martell SJD. 2004. Fisheries Ecology and Management. Princeton University Press, Princeton.

Yongo E, Outa N. 2016. Growth and population parameters of Nile tilapia, Oreochromis niloticus (L.) in the open waters of Lake Victoria, Kenya. Lakes Reserv Res Manag 21: 375-379. DOI: 10.1111/lre.12154.

Yusifa N, Yanto A, Sairiyyah S, Isa M. 2019. Investigation of water level shrinkage of Aneuk Laot Based on Minor Fault With Remote Sensing Method. J Aceh Phys Soc 8 (2): 47-54. DOI: 10.24815/jacps.v8i2.11246. 